\title{
MICROSTRUCTURE OF A JOINT OF SINTERED CARBIDES AND STEEL BRAZED WITH Ag-Cu-Zn-Mn-Ni FILLER METAL
}

\author{
MIKROSTRUKTURA SPOJA SINTRANIH KARBIDNIH TRDIN IN \\ JEKLA SPAJKANIH S SPAJKO NA OSNOVI Ag-Cu-Zn-Mn-Ni
}

\author{
Marcin Karpiński \\ Institute of Non-Ferrous Metals, Sowinskiego 5, 44-100 Gliwice, Poland \\ Prejem rokopisa - received: 2019-08-01; sprejem za objavo - accepted for publication: 2019-02-12
}

doi:10.17222/mit.2019.183

\begin{abstract}
The article presents observations of the microstructure of stainless steel and cemented carbides brazed with the sandwich alloy Ag-Cu-Zn-Mn-Ni with a copper core in a 1:2:1 ratio. The filler metal consisted of $10 \%$ less silver and $10 \%$ more copper than the silver-based alloy Ag449 (BAg-22 acc. to the ANSI AWS A5.8 standard). The brazing process was carried out using a brazing torch with the fluoride-chloride flux. As a result, the filler metal successfully wetted both materials and led to a dense connection. A phase analysis was performed. The observations of the micro-areas of the steel, sandwich alloy and cemented carbides were made using energy-dispersive X-ray spectroscopy, wavelength-dispersive X-ray spectroscopy, electron backscatter diffraction and transmission electron microscopy. Microstructural studies were designed to evaluate the brazed joint. The microstructure of the joint was mainly composed of a $\alpha \mathrm{AgZn}$ solid solution and $\alpha \mathrm{CuZn}$-based solid solution. Distributions of the elements in the joining area between the brazing filler metal and cemented carbides showed a higher content of nickel in the brazing area and a lower silver content, approximately $6 \%$ for both alloys. It is noteworthy to mention that there was a cobalt diffusion inside the brazing filler metal. Detailed studies of the chemical composition indicate that the elements with a noticeable diffusion in steel were silver and zinc.

Keywords: brazed cemented carbides, brazed joint analysis, microstructure observation

Avtorji v članku predstavljajo opazovanja mikrostrukture spoja med nerjavnim jeklom in karbidno trdino. Spajkanje so izvedli tako, da se je v sendviču zlitine tipa Ag-Cu-Zn-Mn-Ni, nahajalo bakreno jedro. Razmerje plasti spajke in bakra je bilo 1:2:1 Spajka je vsebovala $10 \%$ manj srebra in $10 \%$ več bakra kot spajka na osnovi srebra Ag449 (BAg-22 v skladu z ANSI AWS A5.8 standardom). Spajkanje so izvedli z uporabo spajkalnika in fluoridno-kloridnega talila. Staljena spajka je uspešno omočila oba materiala in med njima je nastala tesna (neporozna) povezava. Avtorji so nato izvedli fazno analizo nastalega spoja. Opazovanja mikropodročij jekla, nastalega spoja, oz. t.i. sendvič zlitine in karbidne trdine so izvedli s SEM/EDX in WDX spektroskopijo, difrakcijo s povratno sipanimi elektroni (EBSD) in elektronsko presevno mikroskopijo (TEM) z namenom ovrednotenja izdelanega spoja. Mikrostruktura spoja je bila $\mathrm{v}$ glavnem sestavljena iz trdnih raztopin na osnovi $\alpha$ AgZn in $\alpha \mathrm{CuZn}$. Porazdelitev elementov v področju spoja med spajko in karbidno trdino nakazuje približno $6 \%$ višjo vsebnost Ni v področju spajkanja in nižjo vsebnost srebra pri obeh zlitinah. Pomembno je še omeniti difuzijo kobalta v področje spoja. Natančnejša študija je pokazala pomembno difuzijo srebra in cinka iz spajke v jeklo.

Ključne besede: spajkanje karbidnih trdin, analiza spajkanih spojev, opazovanje mikrostrukture
\end{abstract}

\section{INTRODUCTION}

Layered brazing alloys are also called sandwich alloys or trimets. These consist of two outer adhesive layers (brazing alloys) and the core that is typically copper or its alloys. ${ }^{1}$ Due to widely different coefficients of heat expansion of hard metals and steel, stresses arise during cooling due to the hindered thermal contraction. This composite is initially free of stress. However, during cooling, steel contracts twice as much as the hard metal, causing the warping of the lead, and distorting the component and cracks in the hard metal. ${ }^{2-5}$ The consequence of this is the tensile stress in the surface of the hard metal. In unfavourable situations, this causes cracks and a diminishment of the lifetime of the tool. Trimetal brazing alloys are widely used for brazing tools. They combine the good plastic-deformation properties of copper with the low working temperature of silver

*Corresponding author's e-mail:

marcink@imn.gliwice.pl (Marcin Karpiński) brazing alloys. On cooling after brazing, the stress is reduced due to the plastic deformation of the intermediate copper layer that is relatively soft compared to the brazing alloy and the components being joined. ${ }^{6}$ In the case of brazed joints on brazing areas larger than $100 \mathrm{~mm}^{2}$, hard metals can only be brazed in a stress-free way using trimetal brazing alloys. ${ }^{7}$ The quality of the tools with brazed plates is largely dependent on the course of the brazing process, and proper handling of the tool body, plate inserts and possible intermediary plate of their mutual adjustment, and the proper selection of the solder and fluxing agent (or a protective atmosphere).,5 The thermal stresses arising in a brazed joint, especially in plates with larger dimensions or very fragile plates containing higher amounts of titanium carbide as well as tools operating at a high stress between the plate and the tool body, intermediate insets or a layered adhesive have to be used. ${ }^{6,7}$ The purpose of the introduction is to provide sufficient background information and allow the reader to understand and evaluate the results of the 
present study. It should briefly and clearly describe the purpose of the paper, present as clearly as possible the nature and scope of the problem investigated, review recent literature to inform the reader, state the method of the investigation and, if necessary, the reasons for the choice of a particular method.

\section{EXPERIMENTAL PART}

The base materials used in the experiments were a steel plate and cemented carbide in the form of plates. The chemical composition of carbide included $75 \% \mathrm{WC}$ with a binder layer of $12.5 \% \mathrm{Ni}$ and $12.5 \% \mathrm{Co}$. The trimet used in the process had three layers: the brazing alloy, copper, the brazing alloy in a ratio of $1: 2: 1$. The chemical composition of the used brazing alloy was Ag-38 \% Cu-24\% Mn-7.5\% Ni-4.5\% Zn- the balance, the core $-99.95 \%$ copper. The trimet strip had a thickness of $0.35 \mathrm{~mm}$. The torch-brazing process included an oxygen-acetylene flame and fluoride-chloride flux. After slow cooling, the joint was cleaned. After the preparation of samples, the material microstructure was examined. A phase analysis was carried out with a JXA 8230 Jeol microanalyser using WDS. The chemical composition was studied with a focused beam (a diameter of approximately 1 micron) in the area of the boundary. A model analysis of the joint structure was performed using a high-resolution scanning electron microscope with EDS and EBSD. Studies of the structure and chemical analysis were performed using transmission electron microscopy on thin films previously cut out from the sample material, ground and polished electrochemically and thinned with ion techniques.

Table 1: Chemical composition of steel (mass, XRF)

\begin{tabular}{|c|c|c|c|c|c|c|c|c|c|}
\hline $\begin{array}{c}\mathrm{Fe} \\
(\%)\end{array}$ & $\begin{array}{c}\mathrm{Si} \\
(\%)\end{array}$ & $\begin{array}{c}\mathrm{Mn} \\
(\%)\end{array}$ & $\begin{array}{c}\mathrm{C} \\
(\%)\end{array}$ & $\begin{array}{c}\mathrm{Cu} \\
(\%)\end{array}$ & $\begin{array}{c}\mathrm{Al} \\
(\%)\end{array}$ & $\begin{array}{c}\mathrm{P} \\
(\%)\end{array}$ & $\begin{array}{c}\mathrm{S} \\
(\%)\end{array}$ & $\begin{array}{c}\mathrm{Cr} \\
(\%)\end{array}$ & $\begin{array}{c}\mathrm{Ni} \\
(\%)\end{array}$ \\
\hline 98.47 & 0.41 & 0.40 & 0,22 & 0.18 & 0.15 & 0.07 & 0.04 & 0.03 & 0.03 \\
\hline
\end{tabular}

\section{RESULTS}

During the microstructure observation of the filler metal before the brazing, two phases were determined:

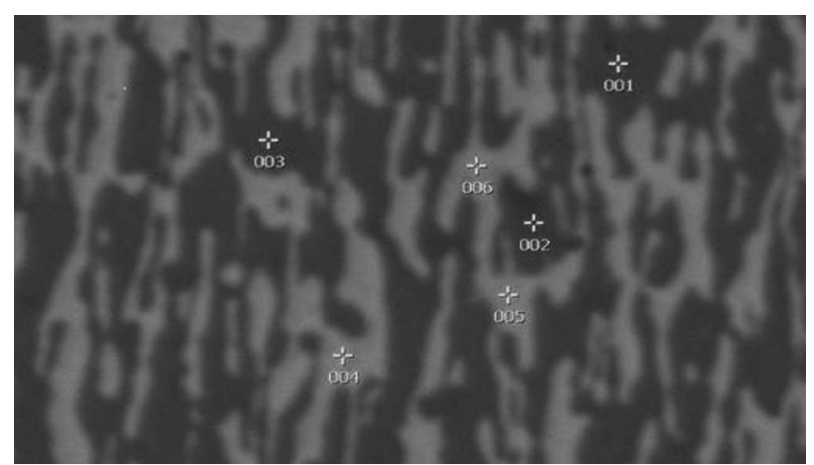

Figure 1: Ag-Cu-Zn_Ni-Mn filler-metal microstructure before brazing

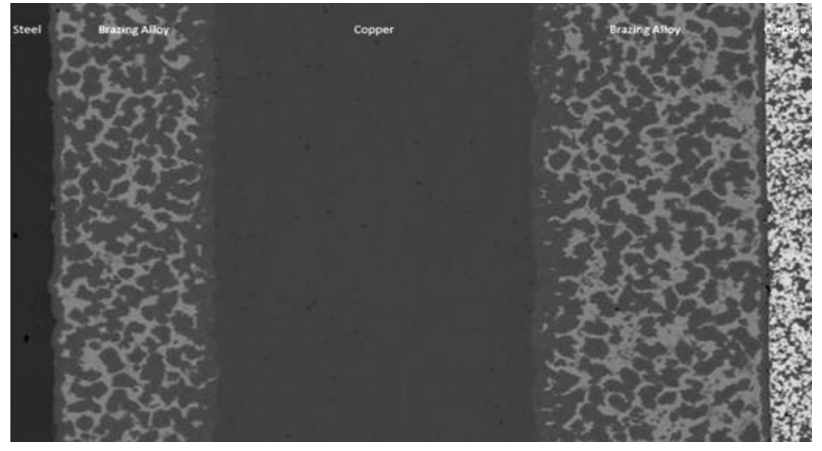

Figure 2: Microstructure of the brazed joint

light and dark. The study showed that the most probable phase, occurring as dark areas, was phase Cu45Zn30Mn12Ni8Ag5, while the light phase corresponded to the composition Ag78Zn15Cu4Mn3Ni. These phases were identified as $\alpha \mathrm{AgZn}$ and $\alpha \mathrm{CuZn}$ in Figure 1.

Table 2: WDS (SEM) point chemical analysis indicated in Figure 1 (dark area, \% mass)

\begin{tabular}{|c|c|c|c|c|c|}
\hline Point 1-3 & $\mathrm{Ag}$ & $\mathrm{Mn}$ & $\mathrm{Ni}$ & $\mathrm{Cu}$ & $\mathrm{Zn}$ \\
\hline Average & 4.8 & 10.7 & 9.0 & 45.5 & 30.0 \\
\hline
\end{tabular}

Table 3: WDS (SEM) point chemical analysis indicated in Figure 1 (dark area, \% mass)

\begin{tabular}{|c|c|c|c|c|c|}
\hline Point 4-6 & $\mathrm{Ag}$ & $\mathrm{Mn}$ & $\mathrm{Ni}$ & $\mathrm{Cu}$ & $\mathrm{Zn}$ \\
\hline Average & 76.0 & 3.5 & 0.7 & 4.9 & 14.9 \\
\hline
\end{tabular}

In his research, M. Hasanabadi et al. ${ }^{8}$ mention the occurrence of distinct zones in different phases: the silver-rich phase, copper-rich phase and Ni-Mn phase. The research presented in this work confirms the occurrence of the silver phase and copper phase. The studies show the occurrence of nickel and manganese in the cooper-rich phase. The microstructures of the areas connecting the brazing alloy with steel and sintered carbides were examined. The microscopic-observation
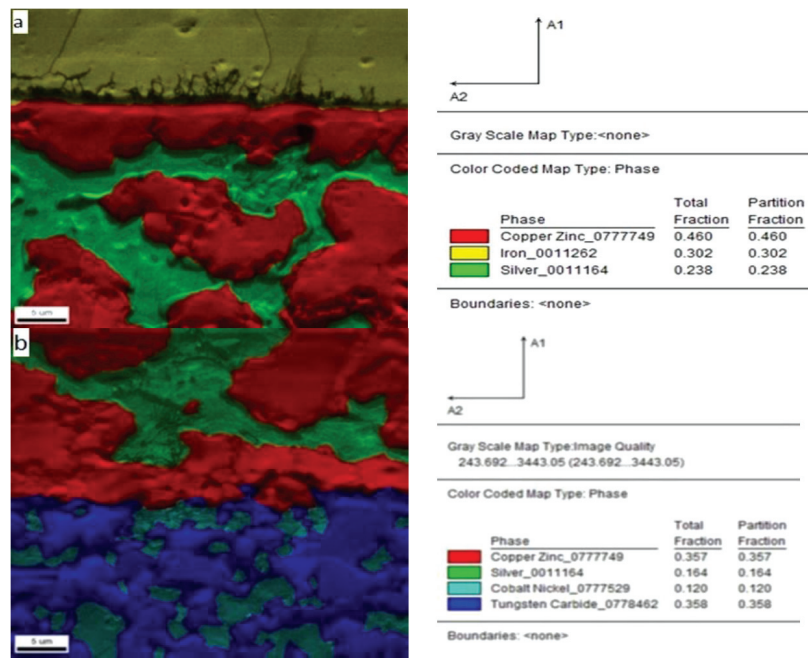

Figure 3: Phases of the brazed joint (EBSD) 


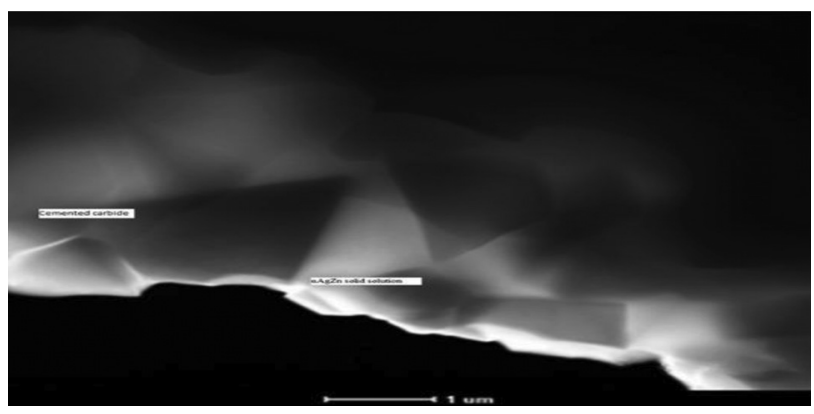

Figure 4: Microstructure of cemented carbides and silver phase $\alpha$ AgZn (TEM)

results obtained by Y. Winardi et al. ${ }^{9}$ show that the dark area is the phase of a $\mathrm{Cu}$-enriched solid solution. Rising treatment temperatures increase the area of the $\mathrm{Cu}$ solid phase. This is because during the solidification process, the $\mathrm{Cu}$ solid phase has more time to grow and develop. The brightest brazing area is the $\mathrm{Zn}$-enriched Ag. ${ }^{9}$

The distributions of elements in the joining area between steel and the brazing filler metal presents a $3 \mu \mathrm{m}$ iron-diffusion area in the brazing filler metal for both alloys. In addition, a $2 \mu \mathrm{m}$ zinc-diffusion area in steel can be seen. The distribution of elements in the joining area between the brazing filler metal and cemented carbides shows a higher content of nickel in the brazing area and a lower silver content of approximately $6 \%$ for both alloys.

It is noteworthy to mention that there is a cobalt diffusion inside the brazing filler metal. Distributions of elements confirm the existence of elements in the boundary regions and their disappearance in the bondedcopper layer. More detailed studies of the chemical composition indicate that the elements that undergo significant, visible diffusion are silver and zinc. This indicates a good diffusion connection between the layers. A previous study states that the cooling rate during solidification has a very important role in the formation of microstructure. ${ }^{10}$

\section{DISCUSSION}

The aims of the structural tests were to assess the quality of the brazed joint of steel and cemented carbides and observe its microstructure. The research was also aimed at showing possible differences or finding similarities in the joint. The microstructure of the joint was mainly composed of a light $\alpha \mathrm{AgZn}$ solid solution and dark $\alpha \mathrm{CuZn}$-based solid solution. Increased amounts of manganese, nickel and cobalt were observed in the area connected with cemented carbides. During the observation of the microstructure using the EBSD technique, a characteristic black area between the brazing alloy and steel was observed. This was probably due to the difficulty in obtaining Kikuchi's diffraction lines at the boundary between the layers, which was reflected in program calculations. The tests revealed the presence of the $\alpha \mathrm{AgZn}$ phase with a high silver content. Diffusion processes between the steel, brazing alloy and cemented carbides led to a heterogeneous chemical composition of the joint.

Micro-areas were reach in copper, manganese and nickel. During the brazing of the cemented carbides, the cobalt diffusion in the brazing alloy was significant (up to $5 \mu \mathrm{m})$. A change in the chemical composition of the alloy was shown, consisting of an increased content of copper in relation to the initial composition. This is partly inconsistent with the results of the work, in which it was stated that copper does not melt and there is no change in the chemical composition of the binder. ${ }^{7}$ Research showed that there is copper diffusion from the core of the sandwich alloy, which blends into the binder during brazing. An analysis of brazed joints between steel and the filler metal binder revealed the existence of copper and zinc diffusion layers in iron and iron in the filler metal. Local differences indicate that elements such as nickel, manganese, cobalt and zinc are present in the area of the carbide and filler metal.

An interesting phenomenon occurred in the joint between a brazing alloy and cemented carbide - increased amounts of manganese, nickel and cobalt were observed in the joint area. The occurrence of manganese and nickel in this area indicates a good connection, which is consistent with the results of this work. In addition, studies showed that the content of tungsten is reduced at the interface of the filler metal and cemented carbide, which is also confirmed by the literature data. ${ }^{7}$ Despite using a filler metal with a reduced silver content, the brazing behaviour was excellent. It is compatible with the literature results, indicating that with a larger amount of silver (over $30 \mathrm{w} / \% \mathrm{Ag}$ ), the brazing behaviour is better and the carbide surface wetting is achieved more easily. ${ }^{12}$

\section{CONCLUSIONS}

Based on the results presented in this work, the following phases were identified in the filler metal: $\alpha-\mathrm{AgZn}$ and $\alpha-\mathrm{CuZn}$. After the brazing process, copper from the intermediate layer reacted, due to diffusion, with the alloy, changing its chemical composition. Increased amounts of manganese, nickel and cobalt were observed in the joint area.

\section{REFERENCES}

${ }^{1}$ H. Schmoor, M. Stroiczek, New sandwich alloy 49/Cu plus improves reliability of saw blades, Proc. of the $3^{\text {rd }}$ Inter. Brazing and Soldering Conference, San Antonio 2006, 344-347

${ }^{2}$ W. Tillmann, N. Sievers, Feasibility study of fluxless brazing cemented carbides to steel, IOP Conf. Series: Mat. Science and Engin., 181 (2017), 012007, doi:1088/1757-899X/181/1/012007

${ }^{3}$ L. Ciura, S. Księżarek, W. Kazana, M. Karpiński, Progress in layered brazing materials with silver content for use in cutting tools, Technological aspects of manufacturing layered materials with silver content, Rudy i Metale Nieżelazne, (2011), 97-102 
${ }^{4}$ M. Karpiński, Silver based brazing composites for trimetalic components, Key Engineering Materials, 641 (2015), 99-104, doi:10.4028/www.scientific.net/KEM.641.99

${ }^{5}$ W. Kazana, L. Ciura, M. Karpiński, Research in the Field of Manufacturing of Layered Brazing Materials, Key Engin. Mat., 641 (2015), 88-92, doi:10.4028/www.scientific.net/KEM.641.88

${ }^{6}$ R. Lofting, Brazing and Soldering, Crowood Press Ltd, Ramsbury 2014

${ }^{7}$ Z. Mirski, Spajanie węglików spiekanych ze stalą, Wyd. Politechniki Wroclawskiej, 2011

${ }^{8}$ M. Hasanabadi, A. Shamsipur, H. Najafisani, H. Omidvar, Interfacial microstructure and mechanical properties of tungsten carbide brazed joints using $\mathrm{Ag}-\mathrm{Cu}-\mathrm{Zn}+\mathrm{Ni} / \mathrm{Mn}$ filler alloy, T. of Nonferrous Met. Soc. of China, 27 (2017), 2638-2646, doi:10.1016/S10036326(17)60292-9

${ }^{9}$ Y. Winardi, Triyono, N. Muhayat, Effect of Post-Braze Heat Treatment on the Microstructure and Shear Strength of Cemented Carbide and Steel Using Ag-Based Alloy, International Conference on Advanced Materials for Better Future, Materials Science and Engineering, Surakarta, 333 (2018), 012039, doi:10.1088/1757$899 X / 333 / 1 / 012039$
${ }^{10}$ S. Akbari Mousavi, P. Sherafat, M. M. Hoseinion, Adv. Mater. Res., (2012), 445759-764

${ }^{11}$ J. Cao, L. X. Zhang, H. Q. Wang, L. Z. Wu, J. C. Feng, Effect of silver content on microstructure and properties of brass/steel induction brazing joint using Ag-Cu-Zn-Sn filler metal, J. Mater. Sci. Technol., 27 (2011) 4, 377-381, doi:10.1016/S10050302(11)60077-7

${ }^{12}$ I. Voiculescu, V. Geanta, H. Binchiciu, D. Iovanas, R. Stefanoiu, Dissimilar Brazed Joints Between Steel and Tungsten Carbide, International Conf. on Innovative Research: Materials Science and Engineering, 209 (2017), 012021, doi:10.1088/1757-899X/209/ $1 / 012021$

${ }^{13}$ M. Hasanabadi, H. Omidvar, A. Shamsipur, Effect of BAg1 Ni-electroplating on microstructure and properties of WC-Co-brazed joints, Material Science and Technology, 33 (2017), doi:10.1018/ 02670836.2017 .1352184 